\title{
PALAEOCURRENT DIRECTIONS AS AN INDICATOR OF PINDOS FORELAND EVOLUTION (CENTRAL AND SOUTHERN PART), WESTERN GREECE J. VAKALAS ${ }^{1}$, G. ANANIADIS ${ }^{1}$, J. MPOURLOKAS ${ }^{1}$, D. POULIMENOS ${ }^{1}$, K. GETSOS ${ }^{1}$, G. PANTOPOULOS ${ }^{1}$, P. AVRAMIDIS ${ }^{1}$, A. ZELILIDIS ${ }^{1}$ \& N. KONTOPOULOS ${ }^{1}$
}

\section{ABSTRACT}

In order to estimate the palaeoflow direction of the submarine fans, deposited in the Internal Ionian subbasin of the Pindos Foreland, fifty-one positions along the sub-basin were selected and measurements of palaeocurrents indicators such as flute and groove marks were taken. In the studied area the main palaeoflow direction of turbidites was axial, from south to north in the southern part, and from north to south in the northern part. A minor westward palaeoflow direction is also present. These palaeoflow directions were influenced mainly by the regional tectonic activity, such as internal thrusting (Gavrovo Thrust) and differential activity of the Pindos Thrust which subdivided Pindos foreland into narrow linear sub-basins.

KEY WORDS: Pindos foreland, Pindos Thrust, Gavrovo Thrust, palaeoflow direction

\section{INTRODUCTION AND GEOLOGICAL SETTING}

Tertiary sediments of Pindos foreland have been interpreted as submarine fan deposits (Piper at al, 1978; Fleury, 1980; Pavlopoulos, 1983; Clews, 1989; Leigh, 1991; Leigh and Hartley, 1992; Wilpshaar, 1995; Avramidis, 1999).

Turbiditic currents are the major way of sediment transportation in a submarine fan. Sediments of a turbidity current (turbidites) are characterized by the "Bouma Sequence" (Bouma, 1962). A complete Bouma sequence is composed of five divisions ( $\mathrm{Ta}, \mathrm{Tb}, \mathrm{Tc}, \mathrm{Td}, \mathrm{Te}$ ) which show an upward decrease in grain size. This decrease reflects the gradual reduce of flow velocity in a turbidity current. Another characteristic of turbiditic deposits is the presence of "sole marks" at the base of sandstone beds. These structures give very important information about the distance from source point (Walker, 1967) and a good view of palaeocurrent directions pattern.

The studied area is part of the Internal Ionian zone (sub-basin in this work) which formed within the Pindos foreland (Brooks et al 1988; Underhill 1989; Clews 1989; Alexander et al., 1990; Avramidis, 1999) and comprises Epirus and Akarnania regions. Pindos foreland is a Tertiary turbiditic foreland basin fill, trending parallel to the external Hellenides and occupies Gavrovo and Ionian geotectonic zones (Aubouin, 1965). The foreland basin is bounded to the east by the Pindos Thrust and to the west by the Ionian Thrust (Fig.1B). The Gavrovo Thrust sub-divided the Pindos foreland into the Gavrovo and Internal Ionian sub-basins. Except these major Thrusts, two minor Thrusts subdivide the Ionian zone into the internal, middle and external Ionian sub-basins (from east to the west)(IGSR\&IFP, 1966)(Fig.1B). Strike-slip faults acting synchronous with the main thrusts influenced the evolution of the basin and the development of depositional environments (King et al, 1993; Avramidis et al, 2000a). The turbiditic deposits of Gavrovo and Internal Ionian zones are considered as a uniform genetic system (Jenkins 1972, Alexander et al 1990, Avramidis et al 2000b). The age of Pindos foreland sediments is still a matter of discussion. B.P. (1971) proposed an early Miocene to middle Miocene age, explaining the presence of Oligocene fauna as a product of large scale erosion and reworking of older sediments during Miocene. IGSR \& IFP(1966) suggested a late Eocene to early Miocene age for the basin fill while Fleury (1980), Leigh (1991), Wilpshaar (1995), Bellas (1997) assigned an Oligocene age. Avramidis et al. (2000a,b) using calcareous nannofosil biozones, propose a middle Eocene to early Miocene age for the basin fill.

Interpretation of palaeocurrent data and facies distributions (B.P. 1971, Piper et al 1978, Alexander et al 1990) indicated that the provenance of Pindos foreland turbiditic deposits is the Pindos front to the east. According to Leigh at al (1992) a major source of sediment was located in the area which today represents the gulf of Patras. Flow within the basin was axial (Leygh 1991). Also, according to Richter et al (1976) in continental Greece the transport of psammitic material was mainly towards the south, but on the Peloponnesus it was

1. Department of Geology, University of Patras, 26500 Patras 


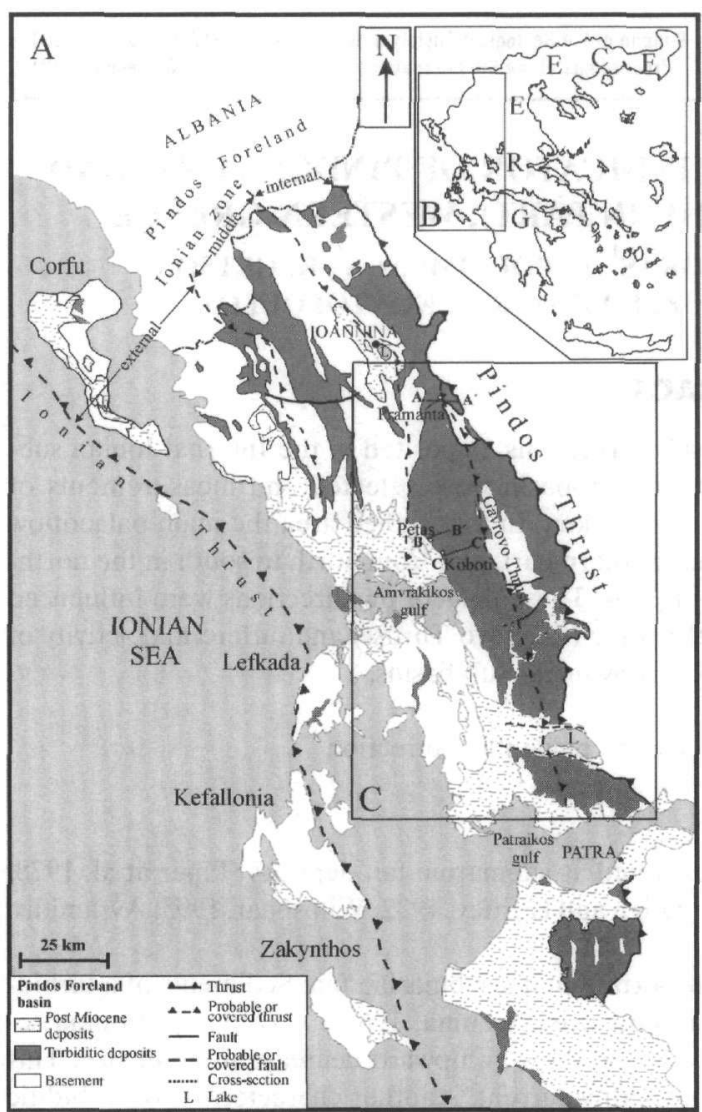

Fig.1: A.Sketch map of Greece showing the northern part of Pindos Fore-land. B.Simpli-fied geological map of the western part of Greece. The inserted box

(C) represents the study area shown in figure 3. towards the north.

The aim of this paper is to use the palaeocurrent directions in the Internal Ionian sub-basin deposits as an indicator for proposing a model for the Pindos foreland basin sediment fill processes by currents.

\section{SEDIMENTOLOGICAL DATA}

Thick coarse-grained deposits were accumulated at the northern (Metsovo-Pramada area) and southern (Mesologgi-Agrinio area) parts of the studied area [mega-debris flow deposits according to Leigh and Hartley, (1992)]. Coarse-grained deposits are absent from both middle and external Ionian sub-basins (Avramidis et al. 2000b). Central part of the studied area is characterized mostly by fine-grained deposits (sandstones - mudstones). All these deposits, which were formed adjacent to the Pindos and Gavrovo Thrusts, mostly represent inner fan deposits. Outer fan deposits were recognized only in the central part of the studied area (Amphilochia-Petas area) where the thickest sediments were accumulated as well.

\section{PALAEOCURRENT ANALYSIS}

Palaeocurrent data (flute and groove marks, Fig. 2) were collected from fifty one positions across the study area. The number of measurements that were collected at each position ranges from 4 to 76 , while the total number of data that are 870 . These data have been plotted in rose diagrams, where the vector mean is also shown. Rose diagrams that comprised a consistency ratio less than 0.7 were not used at the interpretation of the results. Also, data that were collected in beds dipping more than $25^{\circ}$ (less than $10 \%$ of selected measurements) were corrected before their in-

terpretation with rose diagrams. The main part of the measurements concerns positions across three crosssections, trending in an E-W direction (Fig. 3).

The first cross-section (A-A') is located at Epirus region near Pramanta village (Fig. 1). Sixteen positions were studied at this sector, showing two flow directions. The main direction in the western part shows an axial S to SSW flow trend. The second minor direction, refers to the eastern part of the section, and indicates a westward trend in a radial pattern (Fig. 3).

The second cross section (B-B') is located at Akarnania region near Petas village (Fig. 1). Eight locations were studied that show mainly an axial northward trend (Fig. 3). At two locations, at the upper stratigraphic deposits, a minor eastward direction occurs (Fig. 4).

The third cross section (C-C') is also at Akarnania region near Koboti village (Fig. 1). Seventeen locations were selected at this section showing an axial N to NW flow trend (Fig. 3). Two locations at the western part of the section, referring to the lower stratigraphic deposits (Fig. 4), show a WSW and SSE trend.

Ten locations (Fig. 5) were randomly picked across the Akarnania region. The main palaeocurrent directions at these positions are also axial with north or northwest trend (Fig. 3), while a westward direction occurs near the Gavrovo thrust, close to a strike slip fault (Figs 1,3,6). 


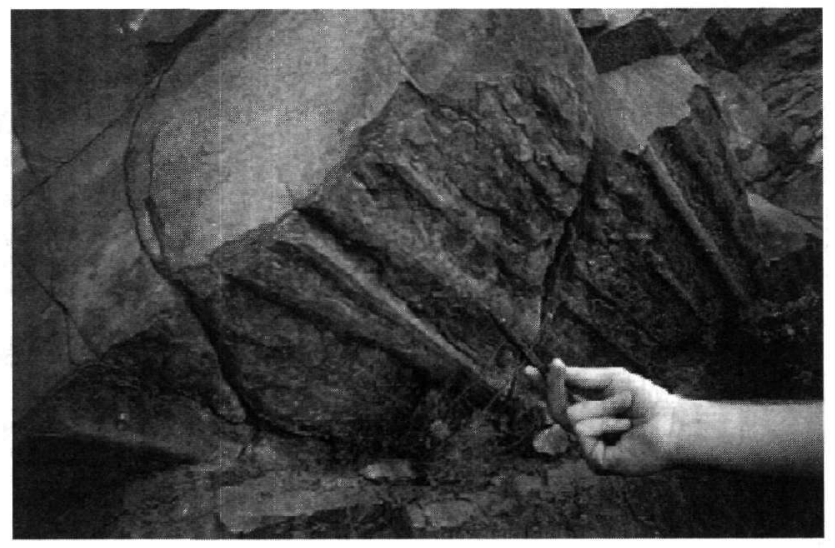

Fig.2 Well preserved groove marks at the base of a thick sandstone bed.

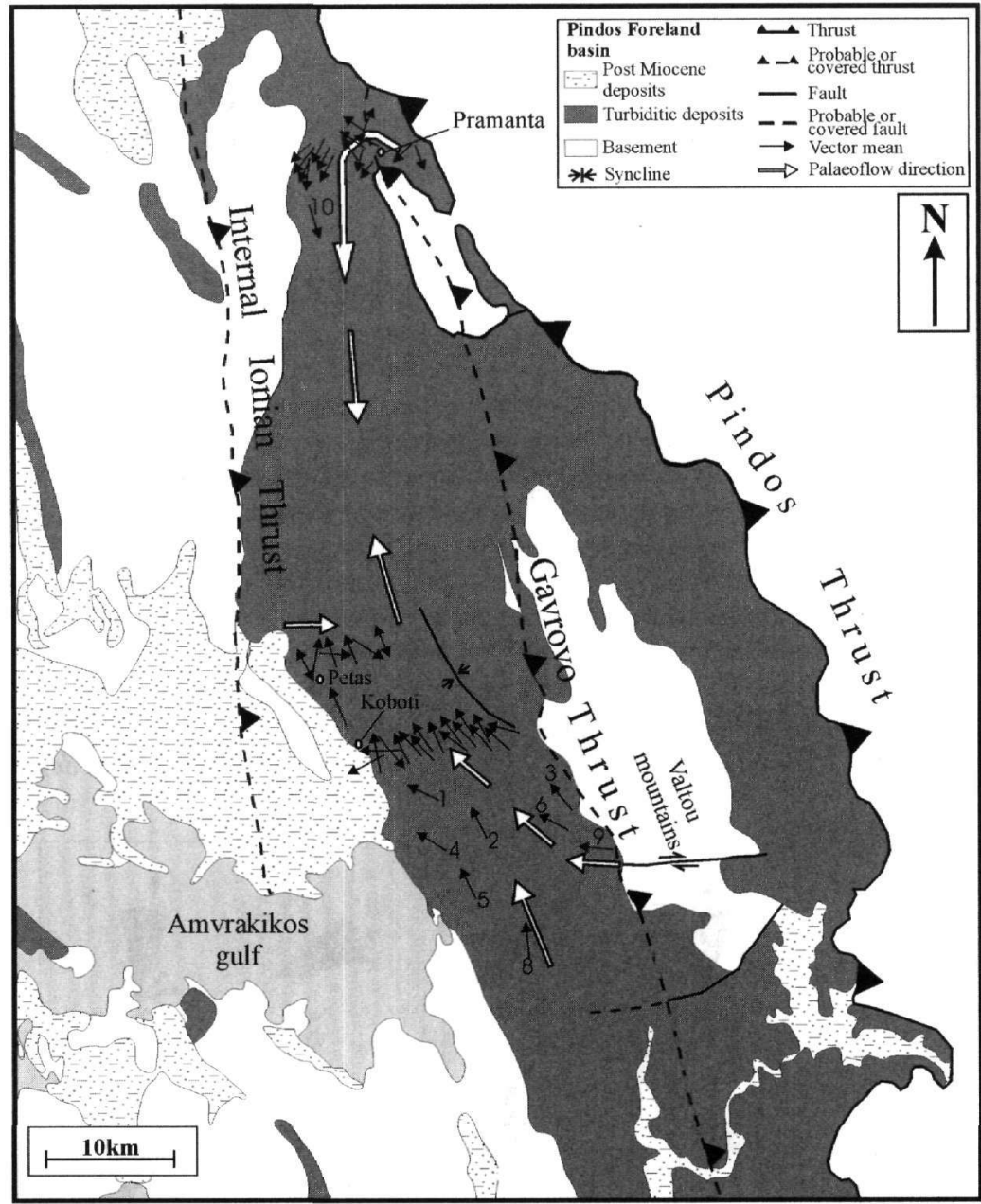

Fig.3 Geological map of the study area. The black arrows represent the vector mean of the rose diagrams at each position. The white arrows are the main paleoflow directions. The numbers from 1-10 refer to the rose diagrams of figure 5, and represent the ten randomly picked positions across the study area. The position of the strike slip fault, in the Valtou mountains, adjacent to Gavrovo Thrust, is also shown. 


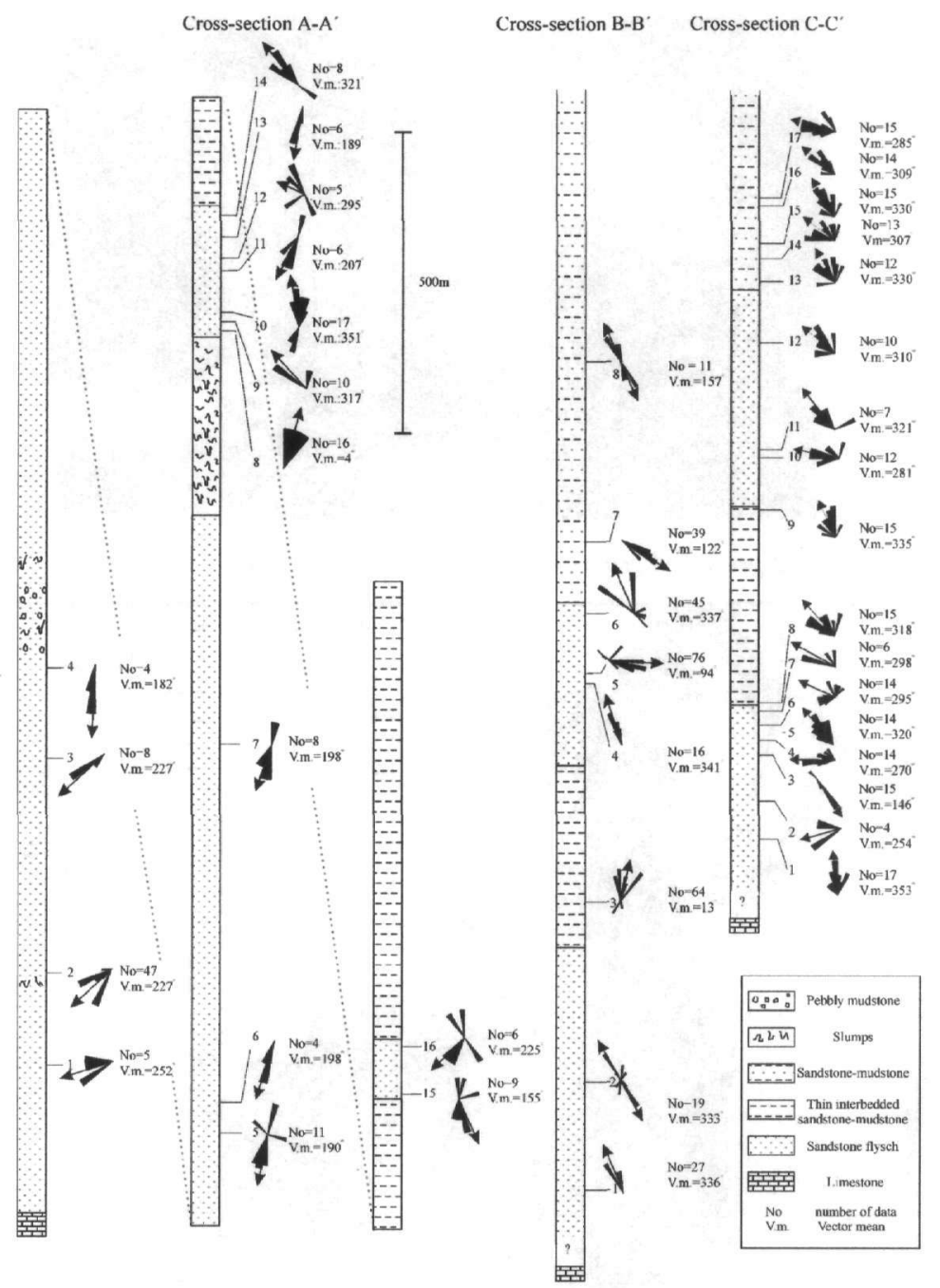

Fig.4: Stratigraphic columns of the cross-sections at $A-A^{\prime}$ (Pramanta), B-B'(Petas) and $C-C^{\prime}$ (Koboti) (for location see figure 1). At the right side of the columns, rose diagrams of palaeocurrent data are plotted.

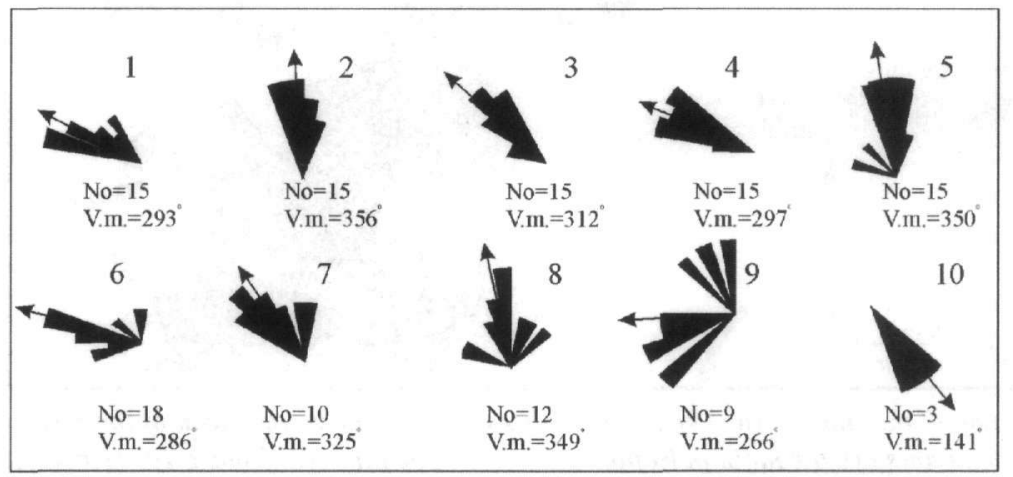

Fig. 5: Rose diagrams of the randomly picked posutions. The first 9 positions are from the central part of the basin and the $10^{\text {th }}$ position is southwards of Pramanta. For location see figure 3. 


\section{DISCUSSION AND CONCLUSIONS}

The palaeocurrent indicators that have been studied in the Internal Ionian sub-basin of Pindos foreland, show two directions, a main one axial and a minor one perpendicular to the Gavrovo and Pindos Thrusts.

\subsection{Axial Direction Interpretation}

The axial direction has two opposite trends :a)a northward trend in the south part of the studied area and b)a southwards trend in the north part of the studied area (Fig. 3). This can be explained by either:

Assuming that there were two major entry points, one in the north end and the other in the southern end of the studied area. This is supported by the presence of coarse-grained sediments in the above margins and by the existence of fine grained material in the central part. The major feeding of the basin were from the southern and northern entry points, influencing the basin fill conditions and the basin configuration (basin depth increasing towards the central part of the basin).

Considering a differential evolution of Pindos and Internal Thrusts (Gavrovo and Internal Ionian Thrust)(Fytrolakis and Antoniou, 1988; Avramidis et al. 2000b).According to this hypothesis when the central part of the Pindos and Gavrovo Thrusts were active during early Oligocene (Avramidis et al, 2000b), forming a foreland basin, their northern and southern parts were inactive or less active than the central part. The northern part was active during middle to late Eocene (Avramidis et al. 2000a) while the southern part was active since late Oligocene (Clews 1989)or early Miocene (Piper et al, 1978).

Taking under consideration the second hypothesis it is easier to interpret the first one.

\subsection{Perpendicular Direction Interpretation}

Perpendicular to the Thrusts trends two palaeocurrent directions were observed, one to the west and the other to the east (Fig. 3).

a) The westwards direction occurs at three locations of the studied area.

- The first location is near Pramanta village, proximal to Pindos Thrust. This indicates a probable source directly from the Thrust front (Figs 1,3).

- The second location is adjacent to Gavrovo Thrust, close to a strike slip fault (Figs 6,7). The presence of the westward direction, probably shows a source point related to a deformed-broken zone due to a strike slip fault activity. The fault affects the relief, forming steep canyons, which lead the sediment to the deeper parts of the foreland basin (Figs 6,7). This interpretation focuses on strike-slip fault activity during the sedimentation as this is also proposed for Agia Kyriaki strike slip fault by King et al. (1993) and Avramidis et al. (2000a).

- The third location is near Koboti village and the palaeocurrent directions were observed in the lower stratigraphic units (Fig. 4). The fact that axial palaeoflow directions were also found at this location (Fig. 3), leads to the hypothesis that while some turbiditic currents flow parallel to basin axis, some others passed to the middle Ionian zone. The presence of an intrabasinal high could also cause this flow behavior. This indicates that probably the influence of internal thrusting to the basin configuration apparently commenced at the early stages of sedimentation (Jordan, 1995).

b) An eastwards direction was recorded in the central part of the basin (Fig. 3), mostly in the upper stratigraphic deposits (Fig. 4), showing a source located to the west. These eastwards directions can be related to intrabasinal highs, which were controlled mainly by the internal thrusting (Gavrovo and Internal Ionian zone Thrusts). Both eastwards and westwards directions can be used as indication of the existence of sub-basins with linear geometry (Jordan, 1995). 


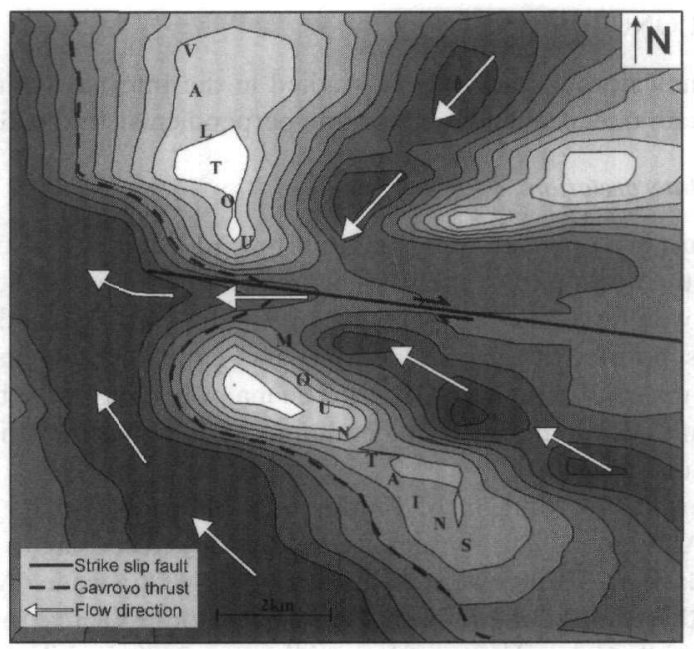

Fig 6: Hypothetical contour map showing the effect of regional tectonic to flow direction. The position of strikeslip fault is shown.

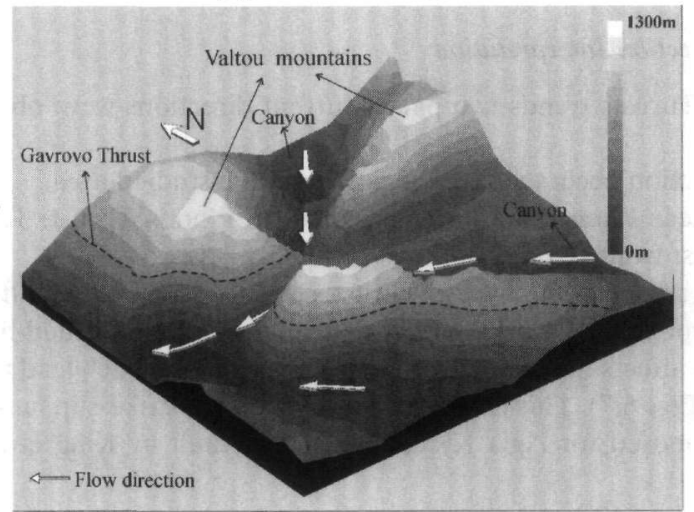

Fig 7: Three dimension view of the previous contour map which gives a better view of how the presence of faults affects the landscape. The location of Valtou mountains is shown in figure 3. Different colour vertical column represents the altitude scale.

\section{REFERENCES}

AUBOUIN, J., (1965) Geosynclines. Elsevier, Amsterdam

ALEXANDER, J., NICHOLS, G. J., LEIGH, S., (1990) The origins of marine conglomerates in the Pindus foreland basin, Greece. Sed. Geol., 66, 243-54

AVRAMIDIS, P., (1999) Depositional environments and hydrocarbon potential of Tertiary formations in KlematiaParamythia basin, Epirus, PhD thesis, University of Patras.

AVRAMIDIS, P., ZELILIDIS, A., KONTOPOULOS, N. (2000a) Thrust dissection control of deep-water clastic dispresal patterns in the Klematia-Paramythia foreland basin, Western Greece. Geol. Mag., 137, (in press).

AVRAMIDIS P., ZELILIDIS P., VAKALAS I., KONTOPOULOS I. (2000b): Interaction between tectonic activity, eustatic sea-level changes and basin configuration of the Pindos foreland and Mesohellenic piggy-back basins, central Greece. $20^{\text {th }}$ Regional European Meeting of Sedimentology, 5.

BELLAS, S. M., (1997) Calcareous nannofossils of the Tertiary flysch (Post Eocene to Early Miocene) of the Ionian zone in Epirus NW-Greece: Taxonomy and Biostratigraphical correlations. Berliner Geow. Abh., 22, $173 \mathrm{pp}$

BOUMA, A. H., (1962) The sedimentology of some flysch deposits : a graphic approach to facies interpretation. Amsterdam, Elsevier, 168pp

BRITISH PETROLEUM CO LTD. (B.P.) (1971) The geological results of petroleum exploration in western Greece. 
Inst. for Geology and Subsurface Research, Special report no. 10, Athens.

BROOKS, M., CLEWS, J., MELIS, N., UNDERHILL, J. R., (1988) Structural development of Neogene basins in western Greece. Basin Ressearch, 1, 129-38

CLEWS, J.,(1989) Structural controls on basin evolution: Neogene to Quartenary of the Ionian zone of western Greece. J. Geol. Soc. London, 146, 447-457.

FLEURY, J. J., (1980), Les zones de Gavrovo-Tripolitza et du Pinde-Olonus(Grece occidentale et Peloponnese du Nord) : evolution d'une plateforme et d'une bassin dans leur cadre alpin. Societe Geologique du Nord, 4, 1651

FYTROLAKIS, N., ANTONIOU, M. (1998) Contribution to the knowledge of the Gavrovou subzone flysch formations, in the Messinia and in the area of the Klokova and Varasova mountains. Bull. Geol. Soc. Greece, XXXII/1, 23-31

IGSR\&IFP, (1966) Etude geologique de l'Epire. Paris: Technip, 306pp.

JENKINS D.A.L. (1972) Structural development of western Greece. AAPG, 56(1), 128-149

JORDAN, T. E. (1995) Retroarc foreland and related basins, in: BUSBY, J. \& INGERSOLL, R. V. (Eds) Tectonics of sedimentary basins, Blackwell Science, 331-362

KING, G., STRUDY, D. \& WHITNEY, J. (1993) The landscape geometry and active tectonics of northwest Greece, Geological Society of America Bulletin 105, 137-61

LEIGH, S. P.,(1991) The sedimentary evolution of the Pindos Foreland Basin Western Greece, Phd thesis. University of Wales.

LEIGH, S. P., Hartley, A.J., (1992) Mega-debris flow deposits from the Oligo-Miocene Pindos foreland basin, western mailand, Greece: implications for transport mechanisms in ancient deep marine basins. Sedimentology, 93, 1003-1012

PAVLOPOULOS, A., (1983) Contribution to the geological investigation of Makrynoros flysch deposits, Akarnania. $\mathrm{PhD}$ thesis, Aristotle University of Thessaloniki, Thessaloniki

PIPER, D. J. W., PANAGOS, A. G., PE, G. G., (1978), Conglomeratic Miocene flysch, western Greece. J. Sed. Petr., 48, 117-26

RICHTER, D., MARIOLAKOS, I., RISCH, H. (1978) The main flysch stages of the Hellenides, in: CLOSS, H., ROEDER, D., \& SCHMIDT, K. (Eds) Alps, Apennines, Hellenides, E. Schweizerbatsche Verlagsbuch-handlung, 434-438

UNDERHILL, J. R., (1985) Neogene and quartenary tectonics and sedimentation in western Greece. Phd thesis, University of Wales, Cardiff.

UNDERHILL, J. R., (1989) Late Cenozoic deformation of the Hellenide foreland, western Greece. Geol. Soc. of Amer. Bul., 101, 613-634

WALKER, R. G., (1967) Turbidite sedimentary structures and their relationship to proximal and distal depositional environments. J. Sed. Petrology, 27, 25-43.

WILPSHAAR, M., (1995) Applicability of dinoflagellate cyst stratigraphy to the analyses of passive and active tectonic settings. Phd thesis, University of Utrecht, Netherlands. 